IZA DP No. 5953

Financial Liberalization and the Brain Drain: A Panel Data Analysis

Aniruddha Mitra James T. Bang

Phanindra V. Wunnava

September 2011 


\title{
Financial Liberalization and the Brain Drain: A Panel Data Analysis
}

\author{
Aniruddha Mitra \\ Middlebury College \\ James T. Bang \\ St. Ambrose University \\ Phanindra V. Wunnava \\ Middlebury College, \\ EPRN and IZA
}

\section{Discussion Paper No. 5953 \\ September 2011}

\author{
IZA \\ P.O. Box 7240 \\ 53072 Bonn \\ Germany \\ Phone: +49-228-3894-0 \\ Fax: +49-228-3894-180 \\ E-mail: iza@iza.org
}

Any opinions expressed here are those of the author(s) and not those of IZA. Research published in this series may include views on policy, but the institute itself takes no institutional policy positions.

The Institute for the Study of Labor (IZA) in Bonn is a local and virtual international research center and a place of communication between science, politics and business. IZA is an independent nonprofit organization supported by Deutsche Post Foundation. The center is associated with the University of Bonn and offers a stimulating research environment through its international network, workshops and conferences, data service, project support, research visits and doctoral program. IZA engages in (i) original and internationally competitive research in all fields of labor economics, (ii) development of policy concepts, and (iii) dissemination of research results and concepts to the interested public.

IZA Discussion Papers often represent preliminary work and are circulated to encourage discussion. Citation of such a paper should account for its provisional character. A revised version may be available directly from the author. 
IZA Discussion Paper No. 5953

September 2011

\section{ABSTRACT}

\section{Financial Liberalization and the Brain Drain: A Panel Data Analysis}

This paper explores the impact of financial liberalization on the migration of high skilled labor from 46 countries to the OECD, taken at five year intervals over the period 1985-2000. Using an exploratory factor analysis, we are able to distinguish between two dimensions of financial liberalization, namely the robustness of the markets and their freedom from direct government control. We find that a standard deviation improvement in the robustness of the source country financial sector magnifies the extent of brain drain by a factor of about four percentage points on the average. However, a corresponding increase in the freedom of the source country financial sector from government control has a modest negative impact on the emigration of high skilled labor and the effect is not statistically significant. Further, the impact of improved financial sector robustness on selection is more pronounced for non-OECD economies than for OECD nations, which experience virtually no impact on skilled emigration.

JEL Classification: F22, O15, P48

Keywords: financial liberalization, brain drain, institutions, immigration

Corresponding author:

Phanindra V. Wunnava

Department of Economics

Middlebury College

Warner Hall 502F

Middlebury, VT 05753

USA

E-mail:wunnava@middlebury.edu 


\section{Introduction}

The advent of globalization has led to profound changes in the global economic fabric and generated an ongoing debate on its consequences. Two themes have come to occupy central positions in the debate: First, as the volume of skilled migration increased dramatically in the last decades of the twentieth century (Docquier and Rapoport, 2011), there has been a resurgence of scholarly interest in the causes and consequences of the brain drain (Commander et al, 2004; Docquier and Rapoport, 2008, 2011). Second, as countries have increasingly undertaken financial liberalization programs over the corresponding period (Abiad et al, 2010), there has been a great deal of interest in the consequences of such policies, especially for developing nations (Bekaert et al, 2005; Eichengreen, 2001; Eichengreen and Leblang, 2003; Levine, 1997, 2001, 2005).

Given the sheer volume of scholarly output generated on both of these questions, it is surprising that the two phenomena have seldom been examined in conjunction. This paper takes an initial step in filling the void by investigating the impact of financial liberalization on the magnitude of brain drain from an economy. We emphasize the multidimensionality of financial liberalization and provide evidence that the various dimensions have differing impacts on the migration of skilled labor: an improvement in robustness of the domestic financial sector, as captured by the development of security markets, improvement in the quality of banking supervision, and removal of stringent restrictions on interest rates and capital, is seen to have a significant positive impact on the magnitude of brain drain. However, an increase in economic freedom in the financial sphere, as captured by the relaxation of directed credit policies, credit ceilings, and reduced state presence in the banking sector, has a smaller and statistically insignificant impact. Further, the impact of former is more pronounced for a lower stage of development than it is for more developed economies: while non-OECD countries experience a substantial increase in skilled migration due to liberalization, OECD countries experience virtually no impact at all.

Moreover, institutional quality in the country of origin plays a critical role; and analogous to financial reform, various aspects of institutional structure differ in their impact on the brain drain: the transparency of governance, as reflected by the quality of bureaucracy and the level of corruption, increase the selection of migrants from an economy. Interestingly, the extent of democratization of a society and the perceived credibility of a regime in terms of its ability to protect property rights, enforce contracts, and implement desired programs has no significant impact on selection.

Our analysis contributes to several areas of inquiry: In addressing the multidimensionality of financial liberalization, we provide a nuanced analysis of the phenomenon itself and its relatively unexplored role in the international migration of skilled labor. Further, in documenting a robust positive impact of improved financial sector efficiency on the selection of emigrants, we identify a potential second order 
impact of financial reform on economic growth, namely, through the creation of skilled diasporas. Finally, in addressing the interplay of financial liberalization with the institutional structure of an economy, it contributes to the literature on institutional determinants of skilled migration (Bang and Mitra, 2011; Bertocchi and Strozzi, 2008).

The paper is organized as follows: Section 2 presents the conceptual foundations of our analysis and a brief review of the relevant literature; Section 3 introduces the data; Section 4 outlines the methodological concerns and our responses to them; Section 5 reports our results; and Section 6 concludes.

\section{Conceptual Foundations and Related Theory}

The first question we explore is whether financial liberalization has a positive or negative impact on the proportion of immigrants from a particular country that are highly skilled. In other words, for a given volume of immigrants from a country, do deeper and freer financial markets improve selection or worsen it? The second is whether or not different aspects of financial liberalization matter differently for selection. Specifically, we ask does the robustness (or depth) of a country's financial sector matter more or less than its level of freedom?

Theories of immigrant selection (Borjas, 1987; Chiswick, 2000) suggest that selection depends on, first, the marginal benefit of migration (measured by the wage differential between the home and destination regions; and, second, the costs of migration (measured in terms of both the explicit moving costs as well as the opportunity costs involved with searching for a job in the destination region). Since financial liberalization alters these incentives differently for high and low skill workers, and, in fact has different impacts on each, the distortionary effects of liberalization (or the lack of it) has an ambiguous effect on the brain drain. We briefly outline the basis for this claim below.

With respect to the first argument, the key to financial liberalization's impact on the brain drain lies in its impact on economic growth. In his summary of some of the early contributions to the literature, Levine (1997) notes that "the preponderance of theoretical reasoning and empirical evidence suggests a positive, first-order relationship between financial development and economic growth.” From a theoretical perspective, betterfunctioning financial markets are said to reduce information and transaction costs and thus improve the allocation of resources across sectors as well as intertemporally (Merton and Bodie, 1995). This generates static economic gains through the more efficient use of existing resources as well as dynamic gains through capital accumulation and technological innovation (Romer, 1986; 1990). A subsequent critical analysis of some of the more recent contributions available from Levine (2005) reveals a similar trend. The consensus in this line of research is that better financial markets, broadly defined, positively impacts growth. 
This growth in turn is expected to have a negative impact on the net benefits of migration across the skill distribution (Vogler and Rotte, 2000). However, high skill workers, who are usually better off prior to liberalization, are likely to receive less of a boost to their incomes when access to financial markets improves (Claessens and Perotti, 2007). Hence, with financial liberalization high skill workers experience less of a decline in the benefits of migrations than low skill workers do, and financial liberalization would improve immigrant selection.

Conversely, if wealth constraints are a significant barrier to migration, then financial liberalization is likely worsen immigrant selection. The reason for this is that high skill workers (who earn higher incomes and come from wealthier families, on average) are more likely to have accumulated some savings to cover the cost of their move than low skill workers. Even if they have not accumulated enough cash savings, their families are more likely to own property or other assets that can be put up as collateral on a loan, and while well developed financial markets will improve the terms of such a loan, it will improve credit accessibility for low skill workers by a much higher margin (Claessens and Perotti, 2007). Thus, we would expect financial liberalization to have a worsening effect on selection through the cost channel.

Combining these separate impacts of financial liberalization on the costs and benefits of migration, it seems that the theoretical impact of improved financial institutions on the quality of immigrants is ambiguous and therefore left as an empirical matter. Further, while there is a vast literature discussing the importance of financial institutions, there is not much attention paid to the distinctions between the freedom of financial markets from government control, and the robustness (or depth) of financial markets. In an effort to fill this gap, we use a factor analysis to identify aspects of financial institutions that represent greater freedom as opposed to those that represent greater levels of robustness in order to explore the question of the economic impacts of financial liberalization in a more nuanced way.

\section{Description of Variables}

To measure the impact of financial reform on the migration of high skilled labor, we estimate the following equation:

$$
\text { HIGH SKILL } L_{i t}=\beta X_{i t}+\gamma Z_{i t}+\varepsilon_{i t} \text {. }
$$

The dependent variable $H I G H$ SKILL $L_{i t}$ denotes the fraction of tertiary educated immigrants from country $i$ in year $t$ in the total combined foreign born population in the six major destination countries in the OECD, namely, Canada, Australia, United States, 
United Kingdom, France, and Germany. ${ }^{1}$ The vector $X_{i t}$ contains a parsimonious set of source country characteristics commonly used in empirical analyses of the brain drain in addition to region dummies for Asia, Europe, Africa, Oceania, and South America. The vector $Z_{i t}$ contains the set of institutional and financial variables, and $\varepsilon_{i t}$ is the idiosyncratic error term.

Data on the dependent variable is taken from Defoort (2008) and is available at five-year intervals over the period 1985-2000, restricting our sample to a balanced panel of 184 observations over the four quinquennial periods under consideration. ${ }^{2}$ A list of countries covered in our analysis is provided in Table A- 1 of the appendix and summary statistics for all variables are presented in Table 1 . The remainder of this section is devoted to a description of the independent variables.

\section{Standard Correlates of International Migration}

The vector $X_{i t}$ contains a parsimonious set of source country characteristics commonly used in empirical analyses of the brain drain in addition to region dummies for Asia, Europe, Africa, Oceania, and South America. For each of the four years in our sample, we include (1) the natural logarithm of GDP per capita, (2) population, and (3) average years of education in each source country; the first two being taken from the World Development Indicators (WDI) and the last from Barro and Lee (2001). In order to control for network effects in international migration as also migration policies specific to the host countries, we also include (4) the total combined foreign-born population from each source country in the six recipient OECD countries, the data again being taken from Defoort (2008).

Prior to describing our variables of interest, it may help to clarify why we include the natural logarithm of GDP per capita in our model rather than GDP per capita itself: recent evidence on international migration reveals a nonlinear impact of GDP per capita in the source country and the incentive to migrate (Vogler and Rotte, 2000; Hatton and

\footnotetext{
${ }^{1}$ Focusing on the six major OECD destinations is less restrictive than may appear to be: The six countries considered accounted for 77\% of the OECD skilled immigration stock in the year 2000 (Beine et al, 2011a and 2011b). This is significant considering that 90 percent of all high skilled international migrants were found to be living in the OECD in that year (Docquier et al, 2007). Further, the United States, Germany, France, Canada, and the United Kingdom were, in descending order, the five largest remittance-sending countries in 2005; together accounting for approximately half of the global remittance flow (Ratha and Shaw, 2007). Australia was the ninth largest, being further superseded by Saudi Arabia, Spain, and Hong Kong in descending order. For other studies based on the Defoort (2008) dataset, see Beine et al (2011a and 2011b), Bang and Mitra (2011b), and Dutta and Roy (2008).

2 The original dataset accounts for migration from 147 source countries at five-year intervals over the period 1975-2000 and may be accessed from http://perso.uclouvain.be/frederic.docquier/oxlight.htm. The unavailability of financial and institutional variables restricts our sample to 52, 60, 53, and 59 countries for the years 1985, 1990, 1995, and 2000 respectively. Leaving out countries that emerged as autonomous political entities over the sample period and others with intermittent availability of data on the control variables gives us our present balanced panel comprising 46 countries in each of the four periods.
} 
Williamson, 2002; Pedersen et al., 2004). ${ }^{3}$ This is generally captured by introducing both GDP per capita and its square as regressors. The potential endogeneity between GDP and the institutional and financial variables described subsequently would require instrumentation of both GDP terms, which is problematic given the relatively small size of our sample. Hence, the potential nonlinearity is captured by introducing the log of GDP per capita as the relevant measure. ${ }^{4}$

\section{Institutional Determinants of International Migration}

The literature on institutions differentiates between de jure and de facto indicators of institutional quality (Acemoglu and Robinson, 2006), where the former represent constitutional constraints on the abuse of government authority and the latter reflect the extent to which such formal constraints translate to actual practice. There has been some concern that de facto indicators do not reflect institutions in the sense of structural characteristics that constrain individual behavior (North, 1982) as much as the outcomes of such characteristics (Glaeser et al, 2004). Nevertheless we follow the literature in restricting our analysis to de facto variables alone: as noted by Pande and Udry (2005), constraints on the abuse of political authority may exist as behavioral norms without being formalized into constitutional precepts. ${ }^{5}$ Equally importantly, even if such formal constraints exist, they are important only to the extent that political actors commit to obeying them (Hall et al, 2010).

The institutional variables used in our analysis consist of three distinct sets of indices. The first set of indices capture the type and continuity of the regime: (5) The Polity Index quantifies the degree of democracy in a country, based on the openness and competitiveness of executive recruitment, constraints on the executive, and the regulation and competitiveness of participation in government and (6) Checks counts the number of checks of power that exist within the government. By contrast, (7) Regime Durability captures the continuity of governance, based on the number of years since the last change in regime. Finally, (8) the Government Stability Index provides an alternative measure of continuity, using information on unity within the government, its legislative strength, and the level of popular support, to capture its ability to stay in office and ensure the continuity of declared programs. The first two variables are taken from the Polity IV

\footnotetext{
${ }^{3}$ On one hand, an increase in GDP per capita in the source country reduces international income differentials and hence the incentive to migrate. On the other hand, it increases the ability to incur the costs of migration and hence, increases the incentive to migrate. Together, the two effects induce a nonmonotonic response of skilled migration to GDP per capita that typically takes the form of an inverted Ushaped relationship. See Vogler and Rotte (2000) for more on the issue.

${ }^{4}$ We reach the exact same conclusions when introduce the two GDP terms. These results are available on request.

${ }^{5}$ Interestingly, North (1982, p. 201-202) himself includes such norms in his definition of institutions: “...a set of rules, compliance procedures, and moral and ethical behavioral norms designed to constrain the behavior of individuals in the interests of maximizing the wealth or utility of principals."
} 
Project of the Center for Systemic Peace and the last from the International Country Risk Guide (ICRG) published by the Political Risk Services Group. ${ }^{6}$

The second set of indices capture the state of electoral competition in the economy: (9) The Legislative Index of Electoral Competition reflects the extent to which multiple political parties were able to compete for seats in the most recent election. By contrast, (10) the Executive Index of Electoral Competition captures the extent to which popular preferences were reflected in the election of the chief executive. (11) The variable Fraud reflects incidents of voter intimidation and electoral fraud that affected the most recent electoral outcomes. Finally, (12) The Political Fractionalization Index measures the dispersion of party representation in the legislature and (13) the Political Polarization Index measures the distance between the executive and the four main parties in the legislature on an ideological scale. All of these variables are taken from the Database of Political Institutions (DPI) published by the World Bank. ${ }^{7}$

The last set of indices capture political practices not directly reflected in the electoral process: (14) The Corruption Index measures the absence of corruption within the political system; (15) the Bureaucratic Quality Index reflects the autonomy of the bureaucracy from political control; and (16) the Investment Profile Index measures the security of property rights, based on the magnitude of expropriation risk, enforcement of contractual agreements, and delays in payments receivable. ${ }^{8}$ All of these variables are taken from the ICRG.

\section{Measures of Financial Liberalization}

The indices used to measure financial liberalization come from the New Database of Financial Reforms compiled by Abiad et al (2010) and include three distinct sets of variables. The first set of indices reflect the absence of policies that limit private enterprise in the financial sector: (17) Privatization captures the absence of state ownership in the banking sector based on the fraction of total sectoral assets controlled by state owned banks; and (18) Entry Barriers captures the absence of participatory constraints in the banking sector such as restrictions on entry, and the range of financial activities, the geographical area of operation, in addition to stringent license requirements faced by both foreign and domestic banks.

The second set of indices reflect the absence of policies that prevent key financial variables from being determined competitively in the relevant markets: (19) Directed Credit captures the absence of high reserve requirements and government mandates that ensure favored sectors a minimum amount of credit or allow them access to credit at

\footnotetext{
${ }^{6}$ See Marshall et al (2009) for a description of the Polity IV variables and the underlying methodology. The document can be accessed at http://www.systemicpeace.org/inscr/p4manualv2009.pdf. Corresponding information for the ICRG variables can be found at the homepage of the PRS Group: http://www.prsgroup.com/ICRG_Methodology.aspx

${ }^{7}$ See Beck et al (2001) for a description of the variables and the underlying methodology.

${ }^{8}$ The risk of expropriation is perhaps the most commonly used measure of property rights used in the literature (Acemoglu et al, 2005; Knack and Keefer, 1995; Rodrik et al, 2004).
} 
subsidized rates; (20) Credit Controls captures the absence of ceilings on the expansion of credit in addition to the absence of directed credit policies; ${ }^{9}$ (21) Interest Rate Controls reflects the absence of government intervention in the determination of deposit and lending rates; and (22) Capital Controls reflects the absence of separate exchange rates for capital and current account transactions in addition to restrictions on the inflow and outflow of international capital.

The last set of indices reflect the presence of policies designed to improve the operation of the financial sector: (23) Banking Supervision captures steps taken to ensure the independence of the banking supervisory agency from executive influence, grant it adequate legal power, and broaden the scope of its coverage; measures designed to improve the efficiency of bank examinations; and steps to enforce the adoption of minimum capital requirements for banks as per the Basle I Capital Adequacy Accord. ${ }^{10}$ Lastly, (24) Security Markets reflects policies designed to encourage the development of security markets, including steps taken to open up domestic equity markets to foreign investors. This concludes our description of data. As previously mentioned, summary statistics for all variables are reported in Table 1.

\section{Methodological Concerns}

Estimating equation (1) confronts us with the following concerns: First, per capita GDP may be endogenous and may, in fact, depend on the institutional variables (Acemoglu et al, 2005; Glaeser et al, 2004; Knack and Keefer, 1995; Rodrik et al, 2004) and measures of financial liberalization (Beck and Levine, 2004; Bekaert et al, 2005, 2011; Levine, 2001, 2005). Hence, estimating (1) using the classical regression model is inherently problematic and we therefore implement a two stage least squares (2SLS) procedure with life expectancy and per capita energy consumption from the WDI as excluded instruments for per capita GDP. The Hansen J- Statistic reported at the foot of Table 3 confirms that the first stage equation is not over- identified. ${ }^{11}$

Second, the institutional variables used in our analysis are highly correlated with each other. The literature has typically addressed the problem of multicollinearity by

\footnotetext{
${ }^{9}$ We could alternatively include Credit Ceilings rather than the combined Credit Controls variable, but this leads to a considerable reduction of our sample. Nevertheless, both our Exploratory Factor Analysis and the final regression exercise yield identical results when we replace (20) with Credit Ceilings. These results are available on request.

${ }^{10}$ The Basel I Accord of 1988 was a set of recommendations on banking sector regulation published by a committee of central bank governors from the Group of Ten nations, called the Basel Committee on Banking Supervision. It was replaced by the more comprehensive Basel II in 2004 and the recent financial crisis has resulted in further modifications in the form of Basel III, though this remains a work in progress. See http://www.bis.org/publ/bcbsca.htm for the original Basel document and subsequent updates.

${ }^{11}$ Given the inherent problem of heteroskedasticity in cross-country growth regressions (Durlauf et al., 2005), we compute robust standard errors of our estimated coefficients, making the Hansen J-Test the appropriate test for over-identification.
} 
constructing unidimensional indices of institutional structure from the available indicators (Alesina and Perotti, 1996; Perotti 1996). ${ }^{12}$ However, this procedure ignores the argument that institutions are best regarded as multidimensional, since various aspects of institutional character may differ in their impact on economic outcomes (Bang and Mitra, 2011a). ${ }^{13}$

Third, the same problem of multicollinearity arises from measures of financial liberalization. Again, this is usually addressed by focusing on specific components of financial liberalization (Beck and Levine, 2004; Bekaert et al, 2005, 2011; Chinn and Ito, 2006) or by combining different aspects of financial liberalization into one aggregate index (Abiad and Mody, 2005; Abiad et al, 2010). ${ }^{14}$ While the first procedure is clearly unsuited to our purpose of tracing out how the global movement towards financial liberalization impacted skilled migration; note that the second procedure is, in principle, subject to the caveat of ignoring the multidimensionality of financial liberalization.

Finally, the financial variables of interest may be correlated with the set of institutional controls, since the adoption of a financial liberalization program may depend on the existing institutional structure (Rajan and Zingales, 2003) and such a program may, in turn, influence subsequent institutional development (Rajan and Zingales, 2003; Bekaert et al, 2011). ${ }^{15}$

To address the last three concerns, we follow Bang and Mitra (2011a) in conducting an Exploratory Factor Analysis (EFA) on the set of financial and institutional variables. This allows us to identify two distinct dimensions of financial liberalization and three distinct dimensions of institutional structure that are orthogonal to each other. These five factors are subsequently included in the vector $Z_{i t}$ of regressors. The remainder of this section is devoted to a description of this procedure.

\section{Multidimensionality of Institutions and Financial Liberalization}

The methodology of EFA is based on the assumption that each of a set of potentially correlated variables is generated by a linear combination of a smaller set latent factors and an individual error term. The hypothesized latent factors include common factors that impact more than one observed variable and specific factors that are unique to each variable. Hence, variation in each of the observed variables can be decomposed into the part caused by variation in the common factors and the part unique to the variable in the

\footnotetext{
${ }^{12}$ Other contributions (Acemoglu et al, 2005; Hall et al, 2011; Rodrik et al, 2004) focus on the subset of institutions that preserve the security of property rights.

${ }^{13}$ Also see Langbein and Knack (2010), who highlight this problem by undertaking a confirmatory factor analysis of the World Governance Indicators (WGI) to determine if these measures are causally related to single latent variable good governance and fail to confirm this hypothesis.

${ }^{14}$ Beck and Levine (2004) on the impact of stock market development; Bekaert et al (2005) on the impact of equity market liberalization; while Bekaert et al (2011) and Chinn and Ito (2006) consider both capital and equity market liberalization. See Levine (2005) for a survey of the finance and growth literature.

${ }^{15}$ See Abiad and Mody (2005) for a dissenting view on the role of institutions as determinants of financial liberalization.
} 
form of specific factors and measurement error. The value of EFA thus lies in its ability to explore a theoretical structure underlying multivariate data: The common factors identified by the method ideally lend themselves to theoretical interpretation. Further, being extracted by identifying common sources of variation in the observed variables, they are, by construction, free of high degrees of multicollinearity. ${ }^{16}$

The EFA conducted on the financial and institutional variables employs the principle component factor extraction method with a promax rotation procedure and factor loadings from this exercise are reported in Panel A of Table 2. The procedure allows us to identify three common factors underlying the observed institutional variables that are interpreted as Democracy, Transparency of Governance, and Credibility of the Regime. We also identify two aspects of financial liberalization that are interpreted as Financial Freedom and Financial Robustness respectively. The remainder of this section will be devoted to clarifying the interpretations of the common factors.

The variables with the greatest weights in the Democracy factor are the Legislative Index of Electoral Competition (0.824), the Executive Index of Electoral Competition (0.880), the Polity Index (0.791), the Political Fractionalization Index (0.727), and Checks (0.614). Note that the first two variables reflect the extent to which the political leadership of a country is determined by free and fair elections as opposed to being determined by dictate; the last two variables capture formal and informal constraints on the exercise of autocratic power; and the Polity Index combines both dimensions. Hence, it is natural to interpret this factor as capturing the extent of democratization of a society.

The factor Transparency is primarily composed of the Bureaucratic Quality Index (0.765), the Corruption Index (0.755), and Regime Durability (0.6235). The first two are clear indicators of the transparency of governance, while Regime Durability may be regarded as an indirect reflection of institutional transparency, since a regime may be durable precisely because it is perceived as operating a transparent administration with an independent and efficient bureaucracy and freedom from corruption.

The factor Credibility is primarily determined by the Investment Profile Index (0.585) and the Government Stability Index (0.569). The former is a direct reflection of the credibility of a regime in terms of being able to protect property rights, enforce contracts, and minimize delays in payments receivable from the government. The Government Stability Index, on the other hand, reflects the credibility of declared policies in terms of their security against radical shifts within the government. As such, it is natural to interpret this factor as capturing the perceived credibility of the government.

The factor Financial Freedom is dominated by Directed Credit (0.956) and Credit Controls (0.947), while the other financial variables play a significant though less

\footnotetext{
${ }^{16}$ For studies using EFA, see Bang and Mitra (2011a) and Langbein and Knack (2010) in the context of institutions; Jong-A-Pin (2009) in the context of political instability; and Headey (2008) in the context of the general determinants of economic growth.
} 
important role. ${ }^{17}$ Note that both of the dominant variables reflect the absence of policies that curtail the freedom of privately owned banks to follow the profit maximization objective. This is also true of the variable Privatization (0.392), which ranks third in terms of weight. As such, we interpret this factor as capturing the freedom of private enterprise in the banking sector. The relevance of this interpretation is highlighted by the fact that our measure of property rights in the form of the Investment Profile Index (0.331) contributes significantly to this factor.

The last factor Financial Robustness is primarily determined by Security Markets (0.632), Capital Controls (0.610), Interest Rate Controls (0.531), and Banking Supervision (0.510). The Security Markets and Banking Supervision variables clearly reflect policies designed to improve the efficiency of the financial sector. Note that a similar case could be made about Capital Controls: Restrictions on the international flow of capital isolate the domestic financial sector from the global economy and compel domestic investors to hold portfolios comprised primarily of domestic securities. This may expose them to a greater degree of risk from shocks arising within the domestic economy, since any portfolio they can hold is likely to be dominated by domestic securities, all of which are subject to the shock. Compensation for the greater degree of risk takes the form of higher expected rates of return on investment, which in turn leads to a higher cost of capital for firms. As such, the absence of such isolating policies improves the efficiency of the financial sector.

The variable Interest Rate Controls lends itself to a similar interpretation: Recall that this variable reflects the absence of government intervention in the determination of interest rates. Such intervention causes a divergence between expected and actual returns on private investment and this may potentially lead to an adverse selection of investment projects. As such, the absence of such forms of intervention contributes to a more efficient financial sector and should be expected to contribute to Financial Robustness.

Finally, as robustness checks, we run the EFA separately for the institutional and financial variables. These exercises yield identical factors as the combined analysis and the corresponding factor loadings are reported in panels B and C of Table 2 respectively. We subsequently replicate the combined analysis using an oblimin rotation procedure and again obtain identical factors. The results of this exercise are available on request.

\section{Results and Robustness}

As mentioned in Section 4, we estimate equation (1) using a 2SLS procedure with life expectancy and per capita energy consumption as excluded instruments for per capita

\footnotetext{
${ }^{17}$ Recall that Credit Controls combines the directed credit variable with the absence of credit ceilings. Since the variation induced by the former is already accounted for by including it separately from the combined variable, the weight of the combined variable is essentially capturing the impact of credit ceilings.
} 
GDP. For the sake of comparison, however, we also include the OLS results for each of our specifications. Thus, even numbered columns in Table 3 present results from the 2SLS exercise and odd numbered columns present the OLS analogues.

As seen from column (2), the principal factor reflecting Financial Robustness has a significant positive impact on the fraction of tertiary educated immigrants: on average, a one standard deviation increase in this factor increases the magnitude of brain drain by a factor of approximately 0.04 and the effect is significant at the 0.01 level. By contrast, Financial Freedom actually reduces the magnitude of brain drain, even though the impact is statistically insignificant.

The relative importance of the robustness factor as a determinant of brain drain has the following implications: recall that the robustness factor essentially reflects policies designed to enhance the efficiency of the financial sector, such as the development of security markets, improved supervision of banks, and removal of stringent restrictions on the flow of international capital leading to reduced required rates of return on domestic securities. As such, an increase in the robustness factor can be interpreted as an improvement in the quality of domestic financial institutions which is likely to promote a more favorable climate for economic activity in the domestic economy and hence increase the expected domestic returns to skill investment.

On the other hand, the freedom factor essentially represents the absence of interventionist policies curtailing the freedom of private sector banks, particularly with respect to the extension of credit. While a reduction of state intervention in the financial sector will undoubtedly have an impact on the expected returns to skill investment in the country of origin, it would not be wrong to claim that that the primary impact of this is to make the cost of migration easier to incur.

The relative salience of the robustness factor then suggests that the dominant impact of financial liberalization on the brain drain operates via reducing the expected marginal benefits from migration rather than the marginal costs. Further, the reduction in marginal benefit from migration is less for the high skilled than it is for the low skilled. This is consistent with the findings of Keeling (2007; 2008), which suggest that the expected benefits from migration have historically played a more significant role in determining the flow of immigrants.

The second implication is that the depth of the financial sector, as captured by the robustness factor has a greater impact on selection than the freedom of the financial sector. This is again interesting for two reasons: first, it emphasizes the need to adopt a more nuanced view of the role of financial markets in investigating their impacts on economic outcomes. Second, if one considers the outflow of skilled labor a useful indicator of economic conditions prevailing in a country, it suggests that efficient and well regulated financial markets are more important for economic prosperity than ones that are merely free from direct government control. 
With respect to dimensions of institutional character, the democracy factor turns out to be insignificant at any acceptable level. Democratic governments are typically less repressive and more responsive to popular concerns. As such, they may be regarded as creating lower incentives for the construction of grievance, which may act as a key motive for skilled migration (Docquier and Rapoport, 2003). On one hand, therefore, the level of democracy may be expected to have a negative impact on skilled workers' incentives to migrate. On the other hand, if the existence of democracy is taken to correlate with a higher quality of economic institutions, we may expect a positive impact on the selection of migrants (Bang and Mitra, 2011a). Theoretically, therefore, it is not clear what the sign on this factor should be. In fact, it may be argued that it is not so much the character of a regime as a democracy but the quality of public institutions and policies associated with it that have an impact on economic performance. In addition, the extent of democratization may itself depend on other factors, such as the level of ethnic diversity in an economy (Akdede, 2010).

The Transparency of Governance is seen to have a significant positive impact on brain drain at the 0.01 level: A one standard deviation increase in transparency increases the fraction of tertiary educated immigrants by 3.5-5.7 percent on the average. Recall that a high value of the transparency factor reflects a high quality of the bureaucracy, a low level of corruption, and a greater perception of legitimacy of the government by virtue of its ability to deliver public services. In other words, a high value of the transparency factor reflects a high quality of existing institutions. This should predict a more favorable selection of migrants (Bang and Mitra, 2011a). To appreciate this, note that an improvement in the quality of domestic institutions will reduce the marginal benefit from migration over the entire skill distribution, but more so for relatively unskilled workers, who depend more on the services provided by the state and at the same time, are less able to protect themselves from corruption and other forms of rent-seeking behavior. Hence, an improvement in transparency is likely to have a positive impact on brain drain.

As a robustness check, we include dummies for the years 1985, 1990, and 1995. The results of this exercise are reported in columns (3) and (4) of Table 3. The robustness factor is again seen to have a significant positive impact on brain drain, even though the coefficient is smaller in magnitude and the variable is now significant at the 0.10 level. The freedom factor, however, remains statistically insignificant, and the difference between the effect of robustness and that of freedom remains significant at the 0.05 level or higher. Democracy and credibility both remain insignificant and transparency its positive impact at the 0.01 level. Note also that the coefficients on both aspects of institutional character remain fairly stable over the change in specification.

We subsequently replicate our analysis by including the average years of education in 1960 as an independent variable, in order to distinguish between the impact of contemporaneous and past levels of human capital. The exercise is first performed without the time dummies and the results reported in columns (5) and (6) of Table 3. We 
then reintroduce the time dummies and present the corresponding results in columns (7) and (8). While the new variable is insignificant at any level of significance, financial robustness retains both sign and significance in all four specifications, even though it is only significant at the 0.10 level in specification (8). As before, financial freedom remains insignificant and the transparency of governance is seen to have a significant positive impact in all four specifications. Note that the coefficients of the robustness and transparency factors remain fairly stable over the changes in specification, indicating the robustness of these impacts.

Finally, it is natural to ask if the impact of financial liberalization on the magnitude of brain drain depends on the stage of development of an economy. To address this concern, we introduced a dummy variable for non-OECD economies along with terms that interact this variable with financial freedom and financial robustness respectively. For the sake of economy, these results are not included in the paper and may be available on request. Neither aspect of financial liberalization appeared to have had a statistically significant impact on brain drain from OECD economies over the sample period. By stark contrast, non-OECD economies appeared to experience a significant increase in skilled emigration due to improved robustness of the financial sector. In fact, a standard deviation increase in the robustness factor was seen to magnify the outflow of tertiary skilled labor from non-OECD economies by 4.2 - 5.5 percent on the average and the impact was significant at the $1 \%$ level for each of our specifications. Note that this is consistent with intuition: in general, OECD economies may be expected to have deeper and more robust financial markets than their non-OECD counterparts and the impact of a marginal increase in the robustness factor is consequently less for the former.

\section{Conclusion}

This paper investigated the role of financial liberalization as a determinant of brain drain. Using an exploratory factor analysis on twelve commonly used institutional variables and seven indices of financial liberalization, we were able to identify three distinct aspects of institutional character and two distinct dimensions of financial liberalization. The dimensions of institutional quality were seen to relate to the extent of democratization in a society, the transparency of governance, and the perceived credibility of a regime; while aspects of financial reform pertained to the increase of economic freedom in the financial sphere and improved robustness of the financial sector.

Our results reveal that the various aspects of financial liberalization and institutional character have significantly different impacts on the magnitude of brain drain: an improvement in robustness of the financial sector increases the fraction of tertiary skilled immigrants by about four percentage points on the average. However, an increase in economic freedom in the financial sector has an ambiguous impact on the 
outflow of skilled labor. Analogously, an improvement in the transparency of governance increases the magnitude of brain drain, but an increase in the extent of democratization and the credibility of a regime have no significant impact on skilled migration. Further, the impact of financial liberalization on the magnitude of brain drain differs for countries at different stages of development: while OECD countries experienced virtually no impact of financial liberalization on the outflow of skilled labor over the relevant period, non-OECD economies experienced a substantial increase in the volume of skilled emigration.

An insight that emerges from our analysis is that financial liberalization may have a second order impact on the growth prospects of developing economies by way of improving the selection of emigrants. There is reason to believe that the prospect of migration increases the expected returns to skill investment and contributes to human capital formation in the country of origin (Beine et al, 2008). There is also evidence that skilled diasporas facilitate the flow of foreign direct investment (Kugler and Rapoport, 2007); help in the transfer of technology (Docquier and Lodigiani, 2010); and contribute towards the adoption of needed institutional reforms ( $\mathrm{Li}$ and McHale, 2006) in the source countries. All these factors have documented positive impacts on economic growth.

Acknowledgments: We would like to thank Robert Prasch for comments and advice and Sarah King, Christian A. Johnson summer intern at Middlebury College, for her able research assistance. The usual caveat applies.

\section{Bibliography}

Abiad, A., Detragiache, E. and T. Tressel, (2010), A new database of financial reforms, IMF Staff Papers 57(2), 281-302.

Abiad, A. and A. Mody, (2005), Financial Reform: What shakes it? What shapes it?, American economic Review 95(1), 63-88.

Acemoglu, D. and J.R. Robinson, (2006), Economic Origins of Dictatorship and Democracy, Cambridge and New York: Cambridge University Press.

Acemoglu, D., Johnson, S. and J. A. Robinson, (2005), Institutions as the Fundamental Cause of Long-Run Growth, in P. Aghion and S. H. Durlauf (eds.) Handbook of Economic Growth Vol. 1, Amsterdam: Elsevier, 385-472.

Akdede, S.H, (2010), Do more ethnically and religiously diverse countries have lower democratization? Economics Letters 106(2), 101-104.

Alesina, A. and R. Perotti, (1996), Income distribution, political instability, and investment, European Economic Review 40(5), 1203-1228. 
Bang, J.T. and A. Mitra, (2011a), Brain Drain and Institutions of Governance: Educational Attainment of Immigrants to the US 1988-1998, Economic Systems, 35(3), 335-354.

Bang, J.T. and A. Mitra, (2011b), Civil War, Ethnicity, and the Migration of Skilled Labor, Eastern Economic Journal, forthcoming.

Barro, R.J. and J.W. Lee, (2001), International data on educational attainment: Updates and implications, Oxford Economic Papers 53(3), 541-563.

Beck, T., Clarke, G., Groff, A., Keefer, P. and P. Walsh, (2001), New tools in comparative political economy: The Database of Political Institutions, World Bank Economic Review 15(1), 165-176.

Beck, T. and R. Levine, (2004), Stock Markets, Banks, and Growth: Panel Evidence, Journal of Banking and Finance 28(3), 423-442.

Beine, M., Defoort, C., Docquier, F., and C. Ozden, (2011), A panel data analysis of the brain gain, World Development 39(4), 523-532.

Beine, M., Docquier, F., and C. Ozden, (2011), Diasporas, Journal of Development Economics 95(1), 30-41.

Beine, M., Docquier, F., and H. Rapoport, (2008), Brain drain and human capital formation in developing countries: winners and losers, Economic Journal 118 (528), 631-652.

Bekaert, G., Harvey, C.R. and C. Lundblad, (2011), Financial Openness and Productivity, World Development 39(1), 1-19.

Bekaert, G., Harvey, C.R. and C. Lundblad, (2005), Does financial liberalization spur economic growth? Journal of Financial Economics 77(1), 3 - 55.

Bertocchi, G. and C. Strozzi, (2008), International migration and the role of institutions, Public Choice 137(1), 81-102.

Borjas, G.J, (1987), Self-Selection and the Earnings of Immigrants, American Economic Review 77(4), pages 531-553.

Chiswick, B. (2000), Are Immigrants Favorably Self-Selected? An Economic Analysis, in Brettell, C. and J. Hollifield (eds.), Migration Theory: Talking Across Disciplines, New York: Routledge, 61-76.

Chinn, M.D. and H. Ito, (2006), What matters for financial development? Capital controls, institutions, and interactions, Journal of Development Economics 81(1), 16392.

Claessens, S. And E. Perotti, (2007), Finance and Inequality: Channels and Evidence, Journal of Comparative Economics 35(4), 748-773.

Commander, S., Kangasniemi, M., and L. A. Winters, (2004), The brain drain: curse or boon? A survey of the literature, in R. E. Baldwin and L. A. Winters (eds.) Challenges to Globalization: Analyzing the Economics, Chicago: Chicago University Press, 235272. 
Defoort C., (2008), Long-term Trends in International Migration: An Analysis of the Six Main Receiving Countries, Population-E 63 (2), 2008, 285-318.

Docquier, F. and E. Lodigiani, (2010), Skilled migration and business networks, Open Economies Review 21(4), 565-588.

Docquier, F., Lohest, O. and A. Marfouk, (2007), Brain drain in developing countries, World Bank Economic Review 21(2), 193-218.

Docquier, F. and Rapoport, H., (2011), Globalization, brain drain and development, Journal of Economic Literature, forthcoming.

Docquier, F. and Rapoport, H., (2008), Skilled migration: The perspective of developing countries, in J. Bhagwati and G. Hansen (eds.) Skilled migration: prospects, problems and policies, New York: Russell Sage Foundation.

Docquier, F. and H. Rapoport, (2003), Ethnic discrimination and the migration of skilled labor, Journal of Development Economics 70, 159-72.

Durlauf, S.N., Johnson, P.A., and J.R.W. Temple, (2005), Growth Econometrics, in P. Aghion and S. H. Durlauf (eds.) Handbook of Economic Growth Vol. 1, Amsterdam: Elsevier, 555-677.

Dutta, N. and S. Roy, (2011), Do potential skilled immigrants care about political stability at home? Review of Development Economics 15(3), 442-457.

Eichengreen, B., (2001), Capital account liberalization: What do the cross-country studies tell us? World Bank Economic Review 15(3), 341-365.

Eichengreen, B. and D. Leblang, (2003), Capital Account Liberalization And Growth: Was Mr. Mahathir Right? International Journal of Finance and Economics 8, 205224.

Glaeser, E., La Porta, R., Lopez-de-Silanes, F., and A. Shleifer, (2004), Do Institutions Cause Growth? Journal of Economic Growth 9(3), 271-303.

Hall, J.C., Sobel, R.S., and G.R. Crowley, (2010), Institutions, Capital, and Growth, Southern Economic Journal 77(2), 385-405.

Hatton, T.J. and J. G. Williamson, (2002), What Fundamentals Drive World Migration? NBER Working Paper No. w9159, NBER.

Headey, D, (2008), The Principle Components of Growth in the Less Developed Countries, Kyklos 61(4), 568-598.

Jong-A-Pin, R., (2009), On the measurement of political instability and its impact on economic growth, European Journal of Political Economy 25, 15-29.

Keeling, Drew (2008), The Voyage Abstracts of the Cunard Line as a Source of Transatlantic Passenger Fares, 1883-1914, Business Archives: Sources and History 96:15-36.

Keeling, Drew (2007), Costs, Risks, and Migration Networks between Europe and the United States, 1900-1914, Research in Maritime History, 33:113-173. 
Knack, S. and P. Keefer, (1995), Institutions and Economic Performance: Cross-Country Tests Using Alternative Institutional Measures, Economics and Politics 7 (3), 207-227.

Kugler, M. and H. Rapoport, (2007), International labor and capital flows: complements or substitutes? Economics Letters 94 (2), 155-162.

Langbein, L and S. Knack, (2010), The Worldwide Governance Indicators: Six, One, or None? Journal of Development Studies 46(2), 350-370.

Levine, R., (2005), Finance and Growth: Theory and Evidence, in P. Aghion and S. H. Durlauf (eds.) Handbook of Economic Growth Vol. 1, Amsterdam: Elsevier, 865-934.

Levine, R., (2001), International Financial Liberalization and Economic Growth, Review of International Economics 9(4), 688-702.

Levine, R., (1997), Financial Development and Economic Growth: Views and Agenda, Journal of Economic Literature, 35(2), 688-726.

Li, X. and J. McHale, (2006), Does brain drain lead to institutional gain? a cross country empirical investigation, mimeo, University of British Columbia.

Marshall, M.G., Gurr, T. R. and K. Jaggers, (2009), Polity IV ${ }^{\mathrm{TM}}$ Project Dataset Users’ Manual, Center for Systemic Peace, http://www.systemicpeace.org/polity/polity4.htm

Merton, R.C. and C. Bodie, (1995), A Conceptual Framework for Analyzing the Financial Environment, in Crane, D.B., K.A. Froot, and S.P. Mason (eds.), The Global Financial System: A Functional Perspective, Boston: Harvard Business School Press, 3-32.

North, D.C., (1982), Structure and Change in Economic History, New York: W. W. Norton \& Co.

Pande, R. and C. Udry, (2005), Institutions and Development: A View from Below, Economic Growth Center Discussion Paper No. 928, Yale University.

Pedersen, P.J., Pytlikova, M., and N. Smith, (2004), Selection or Network Effects? Migration Flows into 27 OECD Countries, 1990-2000, IZA Discussion Papers No. 1104, Institute for the Study of Labor (IZA)

Perotti, R., (1996), Growth, income distribution, and democracy: what the data say, Journal of Economic Growth 1, 149-187.

Rajan, R.G. and L. Zingales, (2003), The great reversals: the politics of financial development in the twentieth century, Journal of Financial Economics 69(1), 5-50.

Ratha, D. and W. Shaw, (2007), South-south migration and Remittances, World Bank Working Paper No. 102, Washington, D.C.: The World Bank.

Rodrik, D., Subramanian, A. and F. Trebbi, (2004), Institutions Rule: The Primacy of Institutions Over Geography and Integration in Economic Development, Journal of Economic Growth 9(2), 131-165.

Romer, P.M., (1986), Increasing Returns and Long-Run Growth, Journal of Political Economy, 94(5), 1002-37. 
Romer, P.M., (1990), Endogenous Technological Change, Journal of Political Economy, 98(5), 71-102.

Vogler, M. and R. Rotte, (2000), The effects of development on migration: Theoretical issues and new empirical evidence, Journal of Population Economics 13(3), 485-508. 


\section{Tables}

Table 1. Summary Statistics for Balanced Sample

\begin{tabular}{|c|c|c|c|c|c|}
\hline Variable & Source & Mean & S.d. & Min & Max \\
\hline \begin{tabular}{|l} 
Skilled Immigration Rate \\
[Dependent Variable]
\end{tabular} & Defoort (2008) & 0.39567 & 0.13863 & 0.06232 & 0.73945 \\
\hline Total Foreign Born Pop. & Defoort (2008) & 1825090 & 12800000 & 0 & 177000000 \\
\hline Log GDPC & WDI & 7.57402 & 1.57189 & 4.03367 & 11.10080 \\
\hline Population & WDI & 133000000 & 562000000 & 12116 & 6460000000 \\
\hline Average Years of Education & & 5.12490 & 2.96215 & 0.04000 & 12.25 \\
\hline Average Years of Education 1960 & Barro \& Lee (2001) & 3.51616 & 2.54306 & 0.07000 & 9.56 \\
\hline Energy Consumption per Capita & WDI & 0.00200 & 0.00200 & 0.00000 & 0.008 \\
\hline Life Expectancy & WDI & 69.94500 & 7.75200 & 42.69800 & 81.076 \\
\hline Europe (dummy) & & & & 0 & 1 \\
\hline Asia (dummy) & & & & 0 & 1 \\
\hline Africa & & & & 0 & 1 \\
\hline Oceania & & & & 0 & 1 \\
\hline South America & & & & 0 & 1 \\
\hline Directed Credit & Abiad et al. (2010) & 1.57394 & 1.14773 & 0 & 3 \\
\hline Credit Controls & Abiad et al. (2010) & 1.63776 & 1.10945 & 0 & 3 \\
\hline Interest Rate Controls & Abiad et al. (2010) & 1.84507 & 1.31493 & 0 & 3 \\
\hline Entry Barriers & Abiad et al. (2010) & 1.82923 & 1.17472 & 0 & 3 \\
\hline Banking Supervision & Abiad et al. (2010) & 0.85211 & 0.98809 & 0 & 3 \\
\hline Privatization & Abiad et al. (2010) & 1.29578 & 1.19693 & 0 & 3 \\
\hline Capital Controls & Abiad et al. (2010) & 1.72183 & 1.12848 & 0 & 3 \\
\hline Security Markets & Abiad et al. (2010) & 1.53697 & 1.12627 & 0 & 3 \\
\hline Financial Freedom factor & & -0.087 & 0.999 & -2.06 & 1.448 \\
\hline Financial Robustness Factor & & -0.131 & 0.84 & -2.041 & 1.708 \\
\hline Government Stability & ICRG & 7.42807 & 2.28608 & 1 & 12 \\
\hline Investment Profile & ICRG & 6.79443 & 2.47057 & 0 & 12 \\
\hline Corruption & ICRG & 3.12326 & 1.38823 & 0 & 6 \\
\hline Bureaucratic Quality & ICRG & 2.14304 & 1.20235 & 0 & 4 \\
\hline Polity Index & Polity IV & 0.47496 & 7.46416 & -10 & 10 \\
\hline Regime Durability & Polity IV & 21.96160 & 28.07190 & 0 & 196 \\
\hline LEIC & DPI & 5.24315 & 2.19072 & 1 & 7 \\
\hline EIEC & DPI & 5.00928 & 2.18647 & 1 & 7 \\
\hline Electoral Fraud & DPI & 0.12144 & 0.32682 & 0 & 1 \\
\hline Political Fractionalization & DPI & 0.46610 & 0.31641 & 0 & 1 \\
\hline Political Polarization & DPI & 0.33624 & 0.71313 & 0 & 2 \\
\hline Checks & DPI & 2.42028 & 1.68298 & 1 & 17 \\
\hline Democracy Factor & & 0.09400 & 0.89100 & -2.989 & 1.197 \\
\hline Transparency Factor & & 0.16900 & 0.86100 & -2.383 & 1.943 \\
\hline Credibility Factor & & -0.19400 & 0.68700 & -2.789 & 1.443 \\
\hline
\end{tabular}

Number of observations

184 
Table 2. Rotated Factor Loadings (Principle Factor Method; Oblique Promax Rotation Method).

\section{Panel A: Combined Factor Analysis}

\begin{tabular}{|lccccccccc}
\hline Variable & Democracy & Freedom & Transparency & Robustness & Credibility & Factor 6 & Factor 7 & Factor 8 Uniqueness \\
Directed Credit & 0.097 & 0.956 & 0.125 & 0.112 & 0.070 & 0.008 & 0.014 & 0.005 & 0.043 \\
Credit Controls & 0.124 & 0.947 & 0.084 & 0.191 & 0.107 & 0.039 & 0.007 & -0.001 & 0.031 \\
Interest Rate Controls & 0.375 & 0.378 & 0.051 & 0.531 & 0.079 & 0.014 & 0.058 & 0.077 & 0.417 \\
Entry Barriers & 0.213 & 0.368 & -0.032 & 0.475 & 0.171 & 0.034 & 0.021 & 0.261 & 0.494 \\
Banking Supervision & 0.164 & 0.382 & 0.173 & 0.510 & 0.330 & 0.153 & 0.188 & 0.018 & 0.369 \\
Privatization & 0.179 & 0.392 & 0.141 & 0.334 & 0.208 & 0.009 & 0.252 & 0.099 & 0.566 \\
Capital Controls & 0.318 & 0.342 & 0.217 & 0.610 & 0.142 & -0.043 & -0.018 & 0.003 & 0.340 \\
Security Markets & 0.262 & 0.339 & 0.352 & 0.632 & 0.174 & 0.127 & -0.086 & -0.100 & 0.231 \\
Government Stability & -0.048 & 0.298 & -0.008 & 0.221 & 0.569 & 0.023 & -0.024 & 0.017 & 0.535 \\
Investment Profile & 0.121 & 0.331 & 0.226 & 0.302 & 0.585 & 0.016 & 0.023 & -0.005 & 0.391 \\
Corruption & 0.174 & 0.123 & 0.755 & 0.014 & -0.038 & 0.072 & -0.064 & 0.104 & 0.364 \\
Bureaucratic Quality & 0.193 & 0.155 & 0.766 & 0.257 & 0.136 & 0.054 & 0.014 & -0.038 & 0.264 \\
Polity Index & 0.791 & 0.076 & 0.329 & 0.200 & 0.003 & 0.065 & -0.057 & 0.070 & 0.207 \\
Regime Durability & 0.071 & 0.236 & 0.624 & 0.093 & 0.081 & 0.010 & 0.171 & -0.155 & 0.482 \\
Legislative Electoral Competition & 0.825 & 0.171 & 0.007 & 0.105 & 0.025 & -0.076 & 0.064 & 0.021 & 0.269 \\
Executive Electoral Competition & 0.807 & 0.108 & 0.108 & 0.115 & 0.065 & -0.050 & 0.038 & -0.036 & 0.303 \\
Electoral Fraud & -0.112 & 0.111 & -0.405 & -0.168 & -0.080 & -0.083 & 0.242 & -0.080 & 0.704 \\
Political Fractionalization & 0.728 & 0.132 & 0.010 & 0.136 & 0.016 & 0.320 & -0.047 & 0.039 & 0.328 \\
Political Polarization & 0.438 & 0.109 & 0.295 & 0.106 & 0.047 & 0.489 & 0.006 & 0.052 & 0.454 \\
Checks & 0.615 & 0.068 & 0.251 & 0.133 & 0.061 & 0.374 & 0.002 & -0.153 & 0.370 \\
\hline
\end{tabular}

Number of observations 335 
Panel B: Institutional Factor Analysis

\begin{tabular}{|lccccccc} 
Variable & Democracy & Transparency & Credibility & Factor 4 & Factor 5 & Factor 6 & Uniqueness \\
Government Stability & 0.093 & 0.039 & 0.665 & 0.007 & 0.014 & -0.037 & 0.546 \\
Investment Profile & 0.252 & 0.275 & 0.669 & 0.042 & -0.018 & 0.037 & 0.410 \\
Corruption & 0.166 & 0.756 & 0.013 & 0.067 & -0.055 & -0.032 & 0.392 \\
Bureaucratic Quality & 0.296 & 0.737 & 0.240 & 0.082 & -0.006 & 0.015 & 0.350 \\
Polity Index & 0.800 & 0.344 & 0.050 & 0.056 & -0.172 & 0.002 & 0.268 \\
Regime Durability & 0.051 & 0.583 & 0.154 & 0.070 & 0.072 & 0.097 & 0.614 \\
Legislative Electoral Competition & 0.871 & 0.036 & 0.128 & -0.039 & 0.060 & -0.042 & 0.217 \\
Executive Electoral Competition & 0.852 & 0.112 & 0.084 & -0.024 & 0.035 & 0.125 & 0.238 \\
Electoral Fraud & -0.015 & -0.391 & -0.043 & -0.095 & 0.258 & 0.005 & 0.770 \\
Political Fractionalization & 0.788 & 0.057 & 0.120 & 0.270 & 0.009 & -0.159 & 0.263 \\
Political Polarization & 0.448 & 0.363 & 0.056 & 0.452 & -0.033 & -0.034 & 0.458 \\
Checks & 0.667 & 0.263 & 0.046 & 0.359 & -0.006 & 0.116 & 0.341 \\
\hline
\end{tabular}

Number of observations

468

\section{Panel C: Financial Liberalization Factor Analysis}

\begin{tabular}{|c|c|c|c|c|c|}
\hline Variable & Freedom & Robustness & Factor3 & Factor4 & Uniqueness \\
\hline Directed Credit & 0.945 & 0.250 & 0.027 & 0.0350 & 0.421 \\
\hline Credit Controls & 0.928 & 0.324 & 0.010 & -0.015 & 0.340 \\
\hline Interest Rate Controls & 0.465 & 0.617 & 0.005 & -0.018 & 0.402 \\
\hline Entry Barriers & 0.418 & 0.568 & 0.102 & 0.017 & 0.492 \\
\hline Banking Supervision & 0.417 & 0.646 & 0.085 & 0.015 & 0.401 \\
\hline Privatization & 0.393 & 0.476 & 0.066 & 0.082 & 0.608 \\
\hline Capital Controls & 0.409 & 0.658 & -0.016 & 0.036 & 0.398 \\
\hline Security Markets & 0.432 & 0.687 & -0.009 & 0.007 & 0.341 \\
\hline
\end{tabular}

Number of observations

568 
Table 3. Regression Results (Dependent Variable: Skilled Immigration Rate)

\begin{tabular}{|c|c|c|c|c|c|c|c|c|}
\hline Independent Variables & (1) & $(2)$ & (3) & (4) & (5) & (6) & (7) & (8) \\
\hline $\ln ($ GDP per Capita) & $\begin{array}{c}-0.0573 * * * \\
(0.0126)\end{array}$ & $\begin{array}{c}-0.0880^{* * *} \\
(0.0254)\end{array}$ & $\begin{array}{c}-0.0543^{* * *} \\
(0.0126)\end{array}$ & $\begin{array}{c}-0.0809 * * * \\
(0.0255)\end{array}$ & $\begin{array}{c}-0.0573 * * * \\
(0.0129)\end{array}$ & $\begin{array}{c}-0.0903^{* * *} \\
(0.0268)\end{array}$ & $\begin{array}{c}-0.0555^{* * *} \\
(0.0129)\end{array}$ & $\begin{array}{c}-0.0844^{* * *} \\
(0.0266)\end{array}$ \\
\hline Population & $\begin{array}{c}-2.94 \mathrm{e}-10^{* * *} \\
(0)\end{array}$ & $\begin{array}{c}-3.50 \mathrm{e}-10^{* * *} \\
(6.80 \mathrm{e}-11)\end{array}$ & $\begin{array}{c}-2.99 \mathrm{e}-10 * * * \\
(5.05 \mathrm{e}-11)\end{array}$ & $\begin{array}{c}-3.43 \mathrm{e}-10 * * * \\
(6.89 \mathrm{e}-11)\end{array}$ & $\begin{array}{c}-3.44 \mathrm{e}-10^{* * *} \\
(5.80 \mathrm{e}-11)\end{array}$ & $\begin{array}{c}-4.13 \mathrm{e}-10^{* * *} \\
(7.48 \mathrm{e}-11)\end{array}$ & $\begin{array}{c}-3.44 \mathrm{e}-10^{* * *} \\
(5.72 \mathrm{e}-11)\end{array}$ & $\begin{array}{c}-4.02 \mathrm{e}-10^{* * *} \\
(7.34 \mathrm{e}-11)\end{array}$ \\
\hline Total Emigrants to OECD & $\begin{array}{c}-2.68 \mathrm{e}-09 \\
(2.41 \mathrm{e}-09)\end{array}$ & $\begin{array}{l}-1.83 e-09 \\
(2.26 e-09)\end{array}$ & $\begin{array}{c}-2.52 \mathrm{e}-09 \\
(2.39 \mathrm{e}-09)\end{array}$ & $\begin{array}{c}-1.91 \mathrm{e}-09 \\
(2.27 \mathrm{e}-09)\end{array}$ & $\begin{array}{c}-2.16 e-09 \\
(2.44 e-09)\end{array}$ & $\begin{array}{l}-1.24 \mathrm{e}-09 \\
(2.22 \mathrm{e}-09)\end{array}$ & $\begin{array}{l}-2.16 e-09 \\
(2.45 e-09)\end{array}$ & $\begin{array}{l}-1.51 \mathrm{e}-09 \\
(2.27 \mathrm{e}-09)\end{array}$ \\
\hline Average Years of Education & $\begin{array}{l}-0.0152 * * \\
(0.00602)\end{array}$ & $\begin{array}{l}-0.00816 \\
(0.00692)\end{array}$ & $\begin{array}{l}-0.0163 * * \\
(0.00629)\end{array}$ & $\begin{array}{c}-0.0103 \\
(0.00732)\end{array}$ & $\begin{array}{l}-0.0116^{* *} \\
(0.00541)\end{array}$ & $\begin{array}{l}-0.00540 \\
(0.00633)\end{array}$ & $\begin{array}{l}-0.0129 * * \\
(0.00577)\end{array}$ & $\begin{array}{l}-0.00702 \\
(0.00666)\end{array}$ \\
\hline Democracy & $\begin{array}{l}-0.0260 * \\
(0.0138)\end{array}$ & $\begin{array}{l}-0.0250 * \\
(0.0137)\end{array}$ & $\begin{array}{c}-0.0295 * * \\
(0.0147)\end{array}$ & $\begin{array}{l}-0.0271 * \\
(0.0139)\end{array}$ & $\begin{array}{l}-0.0164 \\
(0.0192)\end{array}$ & $\begin{array}{l}-0.0137 \\
(0.0187)\end{array}$ & $\begin{array}{l}-0.0174 \\
(0.0208)\end{array}$ & $\begin{array}{l}-0.0121 \\
(0.0193)\end{array}$ \\
\hline Transparency & $\begin{array}{l}0.0322^{* *} \\
(0.0154)\end{array}$ & $\begin{array}{c}0.0467 * * \\
(0.0194)\end{array}$ & $\begin{array}{l}0.0356^{* *} \\
(0.0155)\end{array}$ & $\begin{array}{l}0.0471^{* *} \\
(0.0190)\end{array}$ & $\begin{array}{l}0.0396^{* *} \\
(0.0178)\end{array}$ & $\begin{array}{l}0.0569 * * \\
(0.0222)\end{array}$ & $\begin{array}{l}0.0433^{* *} \\
(0.0175)\end{array}$ & $\begin{array}{c}0.0584 * * * \\
(0.0216)\end{array}$ \\
\hline Credibility & $\begin{array}{l}-0.00326 \\
(0.0143)\end{array}$ & $\begin{array}{l}0.00270 \\
(0.0145)\end{array}$ & $\begin{array}{l}-0.0167 \\
(0.0214)\end{array}$ & $\begin{array}{l}-0.00875 \\
(0.0218)\end{array}$ & $\begin{array}{c}-0.00494 \\
(0.0150)\end{array}$ & $\begin{array}{c}0.000672 \\
(0.0150)\end{array}$ & $\begin{array}{l}-0.0177 \\
(0.0221)\end{array}$ & $\begin{array}{l}-0.0104 \\
(0.0221)\end{array}$ \\
\hline Financial Freedom & $\begin{array}{l}-0.00683 \\
(0.00840)\end{array}$ & $\begin{array}{l}-0.00623 \\
(0.00836)\end{array}$ & $\begin{array}{c}-0.0111 \\
(0.00893)\end{array}$ & $\begin{array}{l}-0.00874 \\
(0.00862)\end{array}$ & $\begin{array}{l}-0.00706 \\
(0.00868)\end{array}$ & $\begin{array}{l}-0.00597 \\
(0.00867)\end{array}$ & $\begin{array}{l}-0.00893 \\
(0.00918)\end{array}$ & $\begin{array}{l}-0.00543 \\
(0.00890)\end{array}$ \\
\hline Financial Robustness & $\begin{array}{c}0.0401^{* * *} \\
(0.0142)\end{array}$ & $\begin{array}{c}0.0465 * * * \\
(0.0150)\end{array}$ & $\begin{array}{l}0.0332 * * \\
(0.0153)\end{array}$ & $\begin{array}{c}0.0416^{* * *} \\
(0.0161)\end{array}$ & $\begin{array}{c}0.0396 * * * \\
(0.0150)\end{array}$ & $\begin{array}{c}0.0476^{* * *} \\
(0.0163)\end{array}$ & $\begin{array}{l}0.0371 * * \\
(0.0179)\end{array}$ & $\begin{array}{l}0.0481 * * \\
(0.0193)\end{array}$ \\
\hline Average Education in 1960 & & & & & $\begin{array}{l}-0.00646 \\
(0.00542)\end{array}$ & $\begin{array}{l}-0.00560 \\
(0.00529)\end{array}$ & $\begin{array}{l}-0.00639 \\
(0.00558)\end{array}$ & $\begin{array}{l}-0.00676 \\
(0.00544)\end{array}$ \\
\hline Constant & $\begin{array}{c}0.860^{* * * *} \\
(0.136)\end{array}$ & $\begin{array}{c}1.072^{* * *} \\
(0.213)\end{array}$ & $\begin{array}{c}0.827^{* * *} \\
(0.131)\end{array}$ & $\begin{array}{c}1.042^{* * *} \\
(0.209)\end{array}$ & $\begin{array}{c}0.858^{* * *} \\
(0.144)\end{array}$ & $\begin{array}{c}1.090^{* * * *} \\
(0.230)\end{array}$ & $\begin{array}{c}0.870^{* * *} \\
(0.146)\end{array}$ & $\begin{array}{c}1.069 * * * \\
(0.226)\end{array}$ \\
\hline Observations & 184 & 184 & 184 & 184 & 176 & 176 & 176 & 176 \\
\hline R-squared & 0.418 & 0.405 & 0.423 & 0.414 & 0.42 & 0.405 & 0.424 & 0.413 \\
\hline R-Squared & 0.418 & 0.405 & 0.423 & 0.414 & 0.42 & 0.405 & 0.424 & 0.413 \\
\hline F Statistic & 9.45 & 8.265 & 7.7 & 6.93 & 8.366 & 7.319 & 6.878 & 6.184 \\
\hline Robust - Freedom & 0.0469 & 0.0527 & 0.0443 & 0.0504 & 0.0466 & 0.0535 & 0.046 & 0.0536 \\
\hline Standard Error & 0.0176 & 0.018 & 0.0181 & 0.0184 & 0.0181 & 0.0188 & 0.0193 & 0.0199 \\
\hline Hansen J Statistic & & 5.568 & & 5.832 & & 5.358 & & 5.875 \\
\hline $\mathrm{P}(>\mathrm{J})$ & & 0.0183 & & 0.0157 & & 0.0206 & & 0.0154 \\
\hline
\end{tabular}

*** $\mathrm{p}<0.01, * * \mathrm{p}<0.05, * \mathrm{p}<0.1$. All Specifications include region dummies for Europe, Africa, Asia, Oceania, and South America. Specifications (3), (4), (7) and (8) further include time dummies for 1985, 1990, and 1995. 


\section{Appendix}

Table A1: List of Countries ${ }^{18}$

\begin{tabular}{|ll|}
\hline Argentina & Kenya \\
Australia & Korea \\
Austria & Mexico \\
Belgium & Mozambique \\
Bolivia & Netherlands \\
Brazil & New Zealand \\
Canada & Norway \\
China & Paraguay \\
Colombia & Philippines \\
Costa Rica & Portugal \\
Denmark & Senegal \\
Dominican Republic & Singapore \\
Ecuador & South Africa \\
Egypt & Spain \\
El Salvador & Sri Lanka \\
Finland & Sweden \\
France & Tunisia \\
Greece & Turkey \\
India & Uganda \\
Ireland & United Kingdom \\
Israel & United States \\
Italy & Uruguay \\
Jamaica & Zimbabwe \\
Japan & \\
\hline
\end{tabular}

18 The unbalanced sample further includes Algeria, Bangladesh, Bulgaria, Cameroon, Chile, Czech Republic, Germany, Ghana, Guatemala, Hungary, Indonesia, Jordan, Malaysia, Nicaragua, Pakistan, Poland, Romania, Thailand, Venezuela, and Vietnam. 